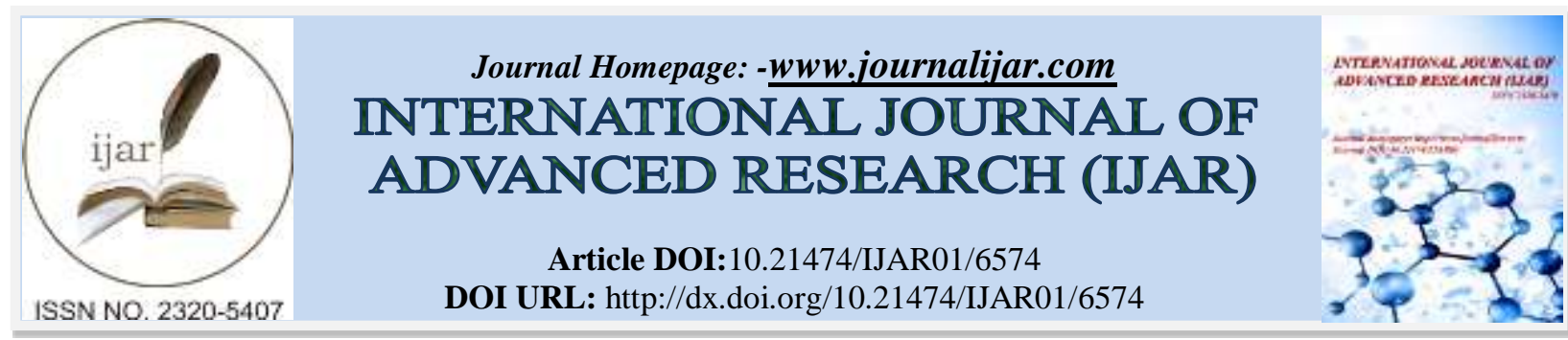

RESEARCH ARTICLE

\title{
CHRONIC SPONTANEOUS URTICARIA FOLLOWING VACCINATION.
}

\section{Eli Magen ${ }^{1,2}$ MD, Gay Shalom MD ${ }^{3}$, MHA; Dan-Andrei Waitman ${ }^{1}$ MD, MPH; Natan R. Kahan ${ }^{1,4}$ RPh, MHA,} PhD.

1. Leumit Health Services, Tel Aviv, Israel.

2. Medicine C Department, Allergy and Clinical immunology Division, Barzilai Medical Center, Ben Gurion University of the Negev, Israel.

3. Department of Dermatology and Venereology, Soroka Medical Center, Beer Sheva, Israel.

4. School of Public Health, Sackler Faculty of Medicine, Tel-Aviv University, Tel-Aviv, Israel.

\section{Manuscript Info}

\section{Manuscript History}

Received: 18 December 2017

Final Accepted: 20 January 2018

Published: February 2018

Keywords:-

Chronic; Spontaneous; Urticaria; Vaccination; ASIA; Shoenfeld; Syndrome.

\section{Abstract}

Autoimmune/auto-inflammatory syndrome induced by adjuvants (Shoenfeld's syndrome) has been suggested for symptoms which appear following vaccination or exposure to several adjuvants. We hypothesized that CSU might be a part of Shoenfeld's syndrome following vaccination.

We studied all 1197 cases of CSU to identify patients that had received vaccinations during the twelve weeks prior the first documentation of CSU symptoms and identified 14 eligible subjects who developed CSU with 12 weeks of vaccination. Dates of vaccinations, local and immediate adverse events, as well as clinical manifestations and their temporal relation to the vaccinations were collected. The Shoenfeld's syndrome criteria were applied to each patient. Eight of the 14 patients (57.1\%) were females. Three $(21.4 \%)$ patients received HBV vaccine (all three patients received two doses at month 0 and 1 of $\mathrm{HBV}$ vaccine inoculations), 3 (21.4\%) received HPV vaccine (one dose), 4 (28.6\%) received influenza vaccine, $2(14.3 \%)$ received Yellow fever vaccine and $2(14.3 \%)$ received DTP vaccine. The mean latency period from last vaccination and onset of CSU symptoms was 8.4 days. Autologous serum skin test was positive in $9(64.3 \%)$ patients. Other clinical manifestations included postural intolerance, tension headaches, sleep disturbances, chronic fatigue, arthralgia, myalgia and irritable bowel disease. Anti-nuclear antibodies were positive in $6(42.8 \%)$ patients, 4 $(28.5 \%)$ tested positive for anti-SSA and anti SSB, 2 (14.3\%) patients for anti-RNP. Either anti-TPO or anti-thyroglobulin antibodies were detected in $10(71.4 \%)$ patients.

This study suggests an association between vaccinations and CSU, as part of the Shoenfeld's syndrome. Further studies are needed to support our observation and to elucidate the pathogenesis of the syndrome. 


\section{Introduction:-}

Chronic urticaria, defined as the recurrent occurrence of wheals with or without angioedema for longer than 6 weeks, can be classified into spontaneous or inducible forms (1). The majority of studies carried out during the last 25 years have shown that diverse biologic mechanisms (i.e. inflammation, autoimmunity, auto-allergy, or coagulation) may interplay to produce the clinical manifestations that characterize chronic spontaneous urticaria (CSU) (2). More than 30 years ago, Grattan and colleagues demonstrated that CSU is characterized by circulating histamine-releasing factors and since then, a positive autologous serum skin test (ASST) has been considered as a marker of "autoreactivity" (3). Nevertheless, the ASST is positive in only about one half of CSU patients (4). Another important step in CSU research was the demonstration of circulating and functionally active IgG histamine releasing autoantibodies directed against either the high-affinity IgE receptor (FceRI) or membrane-bound IgE, suggesting an autoimmune origin $(5,6)$. Recently, the autoimmune pathogenesis hypothesis has received strong support from the detection of circulating autoreactive CD4+ T cells responding to FceRI in $>50 \%$ of patients with CSU (7). Moreover, it has become clear that CSU is characterized by systemic low grade inflammation $(8,9)$.

Recently, the term "autoimmune/auto-inflammatory syndrome induced by adjuvants" (ASIA or Shoenfeld's syndrome) has been suggested for symptoms which appear following vaccination or exposure to several adjuvants $(10,11)$. Shoenfeld's syndrome includes four major and four minor criteria, and in order to diagnose the syndrome, it is required to find two major, or one major plus two minor criteria (10).

In our present study, we have evaluated the clinical cases of 14 patients who were diagnosed with CSU following vaccination. We have analyzed their clinical features and applied the recently suggested criteria of Shoenfeld's syndrome. We hypothesized that CSU might be a part of Shoenfeld's syndrome following vaccination.

\section{Patients and methods:-}

We analyzed a large population of consecutive 1197 Israeli CSU patients age 12 and older who were referred to our outpatient allergy clinic of Leumit Healthcare Services (LHS) from the Ashdod Region (Ashdod, Israel) between January 2008 and May 2017 with a diagnosis of urticaria of at least 6-week duration. LHS covers about 740,000 residents of Israel, and its electronic database includes comprehensive information on the insured population, such as demographic data, records of clinical visits; vaccinations, laboratory tests performed at a single centralized laboratory and diagnostic codes using the International Classification of Diseases, 9th Revision, Clinical Modification (ICD-9-CM). The medical records of the patients were evaluated for demographics and medical history. In addition, dates of vaccinations, local and immediate adverse events, as well as clinical manifestations and their temporal relation to the vaccinations were collected. All available blood tests and imaging studies were also analyzed. The Shoenfeld's syndrome criteria were applied to each patient.

We studied all 1197 cases of CSU to identify patients that had received vaccinations during the twelve weeks prior the first documentation of CSU symptoms and identified 14 eligible subjects who developed CSU with 12 weeks of vaccination. Their electronic medical records were investigated to calculate prevalence of clinical presentations as follows: type of vaccine, interval between vaccination to appearance of CSU, angioedema, symptomatic dermatographism, TPO, anti-thyroid antibodies, clinical manifestations of Shoenfeld's syndrome. All vaccinations were performed according to the CDC protocols.

Clinical and laboratory evaluation and classification of CSU were performed according to the joint initiative of the Dermatology Section of the European Academy of Allergology and Clinical Immunology (EAACI), the EU-funded network of excellence, the Global Allergy and Asthma European Network $\left(\mathrm{GA}^{(2)} \mathrm{LEN}\right)$, the European Dermatology Forum (EDF) and the World Allergy Organization (WAO) EAACI/GA ${ }^{(2)}$ LEN/EDF/WAO guidelines (1).

In our clinic, we routinely apply urticaria activity score (UAS) and perform ASST at the first visit. As urticaria symptoms frequently change in intensity, we usually use in routine clinical practice the UAS 7, mean of the sum of the UAS from the previous 7 days and fix it in the medical records. This study was approved by the LHS Institutional Review Committee. ASST was performed with $50 \mu \mathrm{L}$ of the patient's undiluted serum after allowing blood to clot at room temperature for $30 \mathrm{~min}$ and sample blood centrifugation at $500 \mathrm{~g}$ for $10 \mathrm{~min}$, which was then injected intradermally into the volar aspect of the forearm together with simultaneously injected controls, including saline and $10 \mu \mathrm{g} / \mathrm{mL}$ histamine. The mean diameters of the wheals were measured at 30 minutes. The test was considered to be positive if the serum-injected site manifested a wheal with a diameter at least $1.5 \mathrm{~mm}$ greater than that of the saline. 


\section{Results:- \\ Clinical findings:-}

Characteristics of the $14 \mathrm{CSU}$ patients who presented following vaccination are presented in Table 1. Eight of the 14 patients $(57.1 \%)$ were females. Familial history of autoimmunity was documented in three $(21.4 \%)$ of the patients, of which two had a family history of Hashimoto's thyroiditis and one had a family history of type I diabetes. Three (21.4\%) patients received HBV vaccine (all three patients received two doses at month 0 and 1 of HBV vaccine inoculations), 3 (21.4\%) received HPV vaccine (one dose), 4 (28.6\%) received influenza vaccine, 2 $(14.3 \%)$ received Yellow fever vaccine and $2(14.3 \%)$ received DTP vaccine. The mean latency period from last vaccination and onset of CSU symptoms was 8.4 days. The mean UAS at the first visit was $3.4 \pm 1.3$. Eight (57.1\%) patients had concomitant angioedema and $6(42.9 \%)$ had concomitant inducible urticaria (symptomatic dermatographism). ASST was positive in $9(64.3 \%)$ patients. Other clinical manifestations of three CSU patients following vaccination included postural intolerance, tension headaches, sleep disturbances, chronic fatigue, arthralgia, myalgia and irritable bowel disease (Table 1). None of the $14 \mathrm{CSU}$ patients had the early post-vaccination adverse events such as fever, rash, flu-like symptoms and serum sickness disease. All 14 CSU patients were treated with standard licensed doses of nonsedating antihistamines, while $2(14.3 \%)$ of them were resistant to fourfold standard licensed doses of antihistamines and they consequently received omalizumab (XOLAIR®) subcutaneous injections with excellent response.

\section{Laboratory findings:-}

Anti-nuclear antibodies were positive in 6 (42.8\%) patients, 4 (28.5 \%) tested positive for anti-SSA and anti SSB, 2 $(14.3 \%)$ patients for anti-RNP. Either anti-TPO or anti-thyroglobulin antibodies were detected in 10 (71.4\%) patients, while in all cases TSH levels were within the normal ranges (Table 1).

\section{Discussion:-}

To our knowledge this study is a novel investigation of 14 cases of CSU that developed following vaccination, which might suggest an association between these events. Our patients' symptoms began manifesting within 4 weeks after vaccination, an interval between vaccine-exposure and clinical outcome that suggests a potential causal association (12).

Patients with CSU are widely held to often have other autoimmune disorders, as well as the laboratory abnormalities suggesting autoimmunity $(13,14)$. Remarkably, none of these manifestations were present in our patients prior to the first manifestations of CSU following vaccination, proposing that the vaccine may have been the triggering factor. In the observed cases, post vaccination CSU was accompanied with other symptoms (ie, arthralgia, myalgia, chronic fatigue, orthostatic intolerance, sleep disturbances), that are typical symptoms of ASIA. Consequently, all of our patients met two major criteria and most of them exhibited sera-positivity for different autoantibodies (positive ASST, ANA, anti-thyroid antibodies) thus meeting additional minor criteria (Table 2), that classify cases as Shoenfeld's syndrome.

In our patients, the latency period from the last vaccine inoculation to first manifestations of CSU was 8.4 days. Usually, a latency period of 3-6 weeks from vaccination to the appearance of an immune-mediated disease is considered to be significant (15). Still, variable latency periods have been documented in the current medical literature $(12,16)$.

The positive ASST, anti-thyroid antibodies and/or positive ANA results reinforce that postvaccination CSU has autoimmune mechanisms involved in its pathophysiology. These data enable us to hypothesize that CSU might serve as one the autoimmune diseases of Shoenfeld's syndrome. We also suggest that these patients should be screened periodically for other autoimmune diseases, and followed for a long period.

The study has a number of limitations. The main limitation of this study is that as a retrospective study, it may suffer from information bias, because of possible inaccurate clinical records, loss to follow-up and missing data. The next limitation is the small number of study subjects. As we investigated the cases of CSU with presentation within twelve weeks after last vaccine inoculation, it could cause to the exclusion of several cases of postvaccination CSU which could be occur later. Further large-scale studies are needed to support our observation and to elucidate the pathogenesis of this rare phenomenon. 


\section{Conclusion:-}

This study suggests an association between vaccinations and CSU, as part of the Shoenfeld's syndrome. Even though a causative pathophysiologic association was not investigated in the study, a temporal association was clearly apparent in this patient population. The Shoenfeld's syndrome criteria were met in all patients eluding the possible link between Shoenfeld's syndrome and postvaccination CSU. Further studies are needed to support our observation and to elucidate the pathogenesis of the syndrome.

Table 1:- Demographic and clinical characteristics of 14 patients with postvaccination CSU

\begin{tabular}{|c|c|c|c|c|c|c|c|c|c|c|c|c|}
\hline $\mathbf{N}$ & $\begin{array}{c}\text { Age } \\
\text { (years) }\end{array}$ & Sex & $\begin{array}{c}\text { Vaccine } \\
\text { exposure }\end{array}$ & $\begin{array}{l}\text { Time from } \\
\text { the } \\
\text { vaccination } \\
\text { to the } \\
\text { appearance } \\
\text { CSU }\end{array}$ & $\mathbf{A E}$ & SD & $\begin{array}{c}\text { ASST } \\
\text { positive }\end{array}$ & $\begin{array}{c}\text { ANA } \\
\text { positive }\end{array}$ & TSH & TPO & Tg & $\begin{array}{c}\text { Other } \\
\text { clinical } \\
\text { findings }\end{array}$ \\
\hline 1 & 36 & M & $\begin{array}{l}\text { Influenza } \\
\text { vaccine }\end{array}$ & 11 days & - & - & + & - & 2.1 & - & - & $\begin{array}{l}\text { Chronic } \\
\text { fatigue }\end{array}$ \\
\hline 2 & 34 & $\mathrm{~F}$ & $\begin{array}{c}\text { HBV } \\
\text { vaccine }\end{array}$ & 9 days & + & - & - & + & 2.8 & + & + & $\begin{array}{c}\text { Postural } \\
\text { intolerance }\end{array}$ \\
\hline 3 & 24 & $\mathrm{M}$ & $\begin{array}{l}\text { Yellow } \\
\text { fever } \\
\text { vaccine }\end{array}$ & 5 days & - & + & + & - & 1.1 & - & - & $\begin{array}{c}\text { Chronic } \\
\text { fatigue } \\
\text { Sleep } \\
\text { disturbances }\end{array}$ \\
\hline 4 & 47 & M & $\begin{array}{c}\text { DTP } \\
\text { vaccine }\end{array}$ & 6 days & - & - & + & - & 0.9 & - & - & $\begin{array}{c}\text { Myalgia } \\
\text { Sleep } \\
\text { disturbances } \\
\end{array}$ \\
\hline 5 & 39 & $\mathrm{~F}$ & $\begin{array}{l}\text { Influenza } \\
\text { vaccine }\end{array}$ & 4 days & + & + & + & + & 3.6 & + & - & $\begin{array}{c}\text { Arthralgia } \\
\text { Postural } \\
\text { intolerance }\end{array}$ \\
\hline 6 & 23 & M & $\begin{array}{l}\text { Yellow } \\
\text { fever } \\
\text { vaccine }\end{array}$ & 7 days & - & + & + & - & 2.4 & - & - & $\begin{array}{c}\text { Irritable } \\
\text { bowel } \\
\text { disease } \\
\end{array}$ \\
\hline 7 & 13 & $\mathrm{~F}$ & $\begin{array}{c}\text { HPV } \\
\text { vaccine }\end{array}$ & 16 days & + & - & - & + & 1.7 & - & - & $\begin{array}{l}\text { Myalgia } \\
\text { Chronic } \\
\text { fatigue }\end{array}$ \\
\hline 8 & 40 & $\mathrm{M}$ & $\begin{array}{c}\text { HBV } \\
\text { vaccine }\end{array}$ & 5 days & + & - & + & - & 0.6 & - & - & $\begin{array}{c}\text { Tension } \\
\text { headaches }\end{array}$ \\
\hline 9 & 42 & $\mathrm{~F}$ & $\begin{array}{l}\text { Influenza } \\
\text { vaccine }\end{array}$ & 8 days & + & + & + & + & 4.9 & + & + & Arthralgia \\
\hline 10 & 14 & $\mathrm{~F}$ & $\begin{array}{c}\text { HPV } \\
\text { vaccine }\end{array}$ & 5 days & - & + & + & - & 3.8 & + & - & Arthralgia \\
\hline 11 & 13 & $\mathrm{~F}$ & $\begin{array}{c}\text { HPV } \\
\text { vaccine }\end{array}$ & 12 days & + & - & - & - & 1.9 & - & - & Myalgia \\
\hline 12 & 19 & $\mathrm{~F}$ & $\begin{array}{c}\text { HBV } \\
\text { vaccine }\end{array}$ & 14 days & + & - & + & + & 1.5 & + & + & $\begin{array}{c}\text { Postural } \\
\text { intolerance } \\
\text { Sleep } \\
\text { disturbances }\end{array}$ \\
\hline 13 & 27 & $\mathrm{~F}$ & $\begin{array}{l}\text { Influenza } \\
\text { vaccine }\end{array}$ & 9 days & + & - & - & + & 4.4 & + & + & Arthralgia \\
\hline 14 & 31 & M & $\begin{array}{c}\text { DTP } \\
\text { vaccine }\end{array}$ & 7 days & - & + & - & - & 2.9 & - & - & $\begin{array}{c}\text { Sleep } \\
\text { disturbances }\end{array}$ \\
\hline
\end{tabular}


AE -Angioedema; SD - Symptomatic dermatographism; YF -Yellow fever; HBV - hepatitis B virus; HPV human papilloma virus, DTP - diphtheria/tetanus/pertussis; TSH (0.35-4.94 mIU/l) ; $\quad$ TPO - Anti-TPO antibodies $>75 \mathrm{IU} / \mathrm{ml}$; $\mathbf{T g}$ - antithyroglobulin antibodies > $150 \mathrm{IU} / \mathrm{ml}$

Table 2:- The Suggested Criteria of Shoenfeld's syndrome (10) in 14 patients with postvaccination CSU

\begin{tabular}{|c|c|c|c|c|c|c|c|c|c|c|c|c|c|c|}
\hline Major Criteria & \multicolumn{14}{|c|}{ Present in our patients } \\
\hline & 1 & 2 & 3 & 4 & 5 & 6 & 7 & 8 & 9 & 10 & 11 & 12 & 13 & 14 \\
\hline $\begin{array}{l}\text { 1. Exposure to an external } \\
\text { stimuli (infection, vaccine, } \\
\text { and/or immune adjuvants) } \\
\text { prior to clinical } \\
\text { manifestations }\end{array}$ & + & + & + & + & + & + & + & + & + & + & + & + & + & + \\
\hline \multicolumn{15}{|l|}{$\begin{array}{l}\text { 2. The appearance of } \\
\text { "typical" clinical } \\
\text { manifestations }\end{array}$} \\
\hline $\begin{array}{l}\text { Arthralgia and/joint } \\
\text { pain }\end{array}$ & - & - & - & - & + & - & - & - & + & + & - & - & + & - \\
\hline $\begin{array}{l}\text { Myalgia, muscle } \\
\text { weakness }\end{array}$ & - & - & - & + & - & - & + & - & - & - & + & - & - & - \\
\hline $\begin{array}{l}\text { Chronic fatigue, } \\
\text { unrefreshing sleep or } \\
\text { sleep disturbances }\end{array}$ & + & - & + & + & - & - & + & - & - & - & - & + & - & + \\
\hline $\begin{array}{l}\text { Neurological } \\
\text { manifestations }\end{array}$ & - & + & + & - & + & - & - & + & - & - & - & + & - & - \\
\hline $\begin{array}{l}\text { Cognitive impairment, } \\
\text { memory loss }\end{array}$ & - & - & - & - & - & - & - & - & - & - & - & - & - & - \\
\hline Pyrexia & - & - & - & - & - & - & - & - & - & - & - & - & - & - \\
\hline $\begin{array}{l}\text { 3. Removal of inciting } \\
\text { agent induces improvement }\end{array}$ & NA & NA & NA & NA & NA & NA & NA & NA & NA & NA & NA & NA & NA & NA \\
\hline $\begin{array}{l}\text { 4. Typical biopsy of } \\
\text { involved organs }\end{array}$ & NA & NA & NA & NA & NA & NA & NA & NA & NA & NA & NA & NA & NA & NA \\
\hline Minor Criteria & & & & & & Pres & nt in & ur p: & ient & & & & & \\
\hline $\begin{array}{l}\text { 1. The appearance of } \\
\text { autoantibodies }\end{array}$ & + & + & + & + & + & + & + & + & + & + & - & + & + & - \\
\hline $\begin{array}{l}\text { 2. Other clinical } \\
\text { manifestations (i.e., } \\
\text { irritable bowel syn.) }\end{array}$ & - & - & - & - & - & + & - & - & - & - & - & - & - & - \\
\hline $\begin{array}{l}\text { 3. Specific HLA (eg, HLA } \\
\text { DRB1, HLA DQB1) }\end{array}$ & NA & NA & NA & NA & NA & NA & NA & NA & NA & NA & NA & NA & NA & NA \\
\hline $\begin{array}{l}\text { 4. Evolvement of an } \\
\text { autoimmune disease } \\
\text { (ASST positive CSU) }\end{array}$ & + & - & + & + & + & + & - & + & + & + & - & + & - & - \\
\hline
\end{tabular}

NA - Not assessed 


\section{References:-}

1. Zuberbier T, Aberer W, Asero R, Bindslev-Jensen C, Brzoza Z, Canonica GW, Church MK, Ensina LF, Giménez-Arnau A, Godse K, Gonçalo M, Grattan C, Hebert J, Hide M, Kaplan A, Kapp A, Abdul Latiff AH, Mathelier-Fusade P, Metz M, Nast A, Saini SS, Sánchez-Borges M, Schmid-Grendelmeier P, Simons FE, Staubach P, Sussman G, Toubi E, Vena GA, Wedi B, Zhu XJ, Maurer M; European Academy of Allergy and Clinical Immunology; Global Allergy and Asthma European Network; European Dermatology Forum; World Allergy Organization. The EAACI/GA(2) LEN/EDF/WAO Guideline for the defnition, classifcation, diagnosis, and management of urticaria: the 2013 revision and update. Allergy. 2014; 69(7): 868-87.

2. Asero R, Tedeschi A, Marzano AV, Cugno M. Chronic urticaria: a focus on pathogenesis. F1000Res. 2017; 6:1095.

3. Grattan CE, Wallington TB, Warin RP, Kennedy CT, Bradfield JW. A serological mediator in chronic idiopathic urticaria--a clinical, immunological and histological evaluation. Br J Dermatol. 1986; 114(5):583-90.

4. Greaves M. Chronic urticaria. J Allergy Clin Immunol. 2000; 105(4):664-72.

5. Grattan CE, Francis DM, Hide M, Greaves MW. Detection of circulating histamine releasing autoantibodies with functional properties of anti-IgE in chronic urticaria. Clin Exp Allergy. 1991;21(6):695-704.

6. Hide M, Francis DM, Grattan CE, Hakimi J, Kochan JP, Greaves MW. Autoantibodies against the high-affinity IgE receptor as a cause of histamine release in chronic urticaria. N Engl J Med. 1993;328(22):1599-604.

7. Auyeung P, Mittag D, Hodgkin PD, Harrison LC. Autoreactive T cells in chronic spontaneous urticaria target the IgE Fc receptor I $\alpha$ subunit. J Allergy Clin Immunol. 2016; 138(3):761-768.e4.

8. Magen E, Mishal J, Zeldin Y, Feldman V, Kidon M, Schlesinger M, Sthoeger Z. Increased mean platelet volume and C-reactive protein levels in patients with chronic urticaria with a positive autologous serum skin test. Am J Med Sci. 2010;339(6):504-8

9. Kasperska-Zajac A, Sztylc J, Machura E, Jop G. Plasma IL-6 concentration correlates with clinical disease activity and serum C-reactive protein concentration in chronic urticaria patients. Clin Exp Allergy. 2011;41(10):1386-91.

10. Shoenfeld Y, Agmon-Levin N. 'ASIA' - autoimmune/inflammatory syndrome induced by adjuvants. J Autoimmun. 2011;36(1):4-8

11. Perricone C, Colafrancesco S, Mazor RD, Soriano A, Agmon-Levin N, Shoenfeld Y. Autoimmune/inflammatory syndrome induced by adjuvants (ASIA) 2013: Unveiling the pathogenic, clinical and diagnostic aspects. J Autoimmun. 2013;47:1-16.

12. Arbuckle MR, McClain MT, Rubertone MV, Scofield RH, Dennis GJ, James JA, Harley JB. Development of autoantibodies before the clinical onset of systemic lupus erythematosus. N Engl J Med. 2003; 349(16):152633.

13. Confino-Cohen R, Chodick G, Shalev V, Leshno M, Kimhi O, Goldberg A. Chronic urticaria and autoimmunity: associations found in a large population study. J Allergy Clin Immunol. 2012;129(5):1307-13

14. Magen E, Waitman DA, Dickstein Y, Davidovich V, Kahan NR. Clinical-laboratory characteristics of ANApositive chronic idiopathic urticaria. Allergy Asthma Proc. 2015;36(2):138-44

15. Kivity S, Agmon-Levin N, Blank M, Shoenfeld Y. Infections and autoimmity. Trends Immunol. 2009;30(8):409-14

16. Agmon-Levin N, Zafrir Y, Kivity S, Balofsky A, Amital H, Shoenfeld Y. Chronic fatigue syndrome and fibromyalgia following immunization with the hepatitis B vaccine: another angle of the 'autoimmune (autoinflammatory) syndrome induced by adjuvants' (ASIA). Immunol Res. 2014 Dec;60(2-3):376-83. 